\title{
Videopř́ípad jako stavební jednotka IVŠV videowebu pro vzdělávání učitelů anglického jazyka ${ }^{1}$
}

\section{Videocase as a building block of IVŠV videoweb for education of English teachers}

\author{
Eva Minař́ková
}

\begin{abstract}
Anotace: Předkládaný příspěvek má za cíl na ukázce videopřípadu z IVŠV videowebu pro vzdělávání učitelů anglického jazyka představit strukturu videopř́padu, teoretická východiska, ze kterých obsah i struktura videoprrípadů vychází, i cíle, které je možno pomocí videopř́ípadů sledovat. Videopř́ípadem se zde rozumí sekvence z videozáznamu reálné výuky doplněná dalšími materiály (plán hodiny, práce žáků, pracovní listy, komentáře učitele apod.) a podněcujícími otázkami a úkoly. Těžištěm prezentace je reálný př́íklad videopřípadu, na kterém bude ilustrován postup tvorby spolu s teoriemi, o které se autoři videopř́padů při jejich konstrukci opírali (obecná didaktika, didaktika anglického jazyka, teorie kognitivního zatížení, výzkum v oblasti využívání videa v učitelském vzdělávání). Videopřípady a práce $\mathrm{s}$ nimi umožňují sběr kvalitativních a kvantitativních dat a jejich analýzu.
\end{abstract}

Klíčová slova: vzdělávání učitelů, videopřípad, video v učitelském vzdělávání.

\begin{abstract}
Drawing on a typical example of a videocase from IVŠV videweb, the paper aims to illustrate the structure of videocases, the theoretical background that informs their content and structure, and aims that the videocases can help to fulfil. Videocase is a videosequence from a real lesson presented together with other material (lesson plan, pupils' work, worksheets, teacher's commentary etc.) and tasks and questions. The focus of this paper is an example of a videocase through which we will illustrate the development process of videoweb and also the theories that informed the construction of the videocases (didactics, cognitive load theory, research into using video in teacher education etc.). Videocases allow for collecting qualitative and quantitave data and its analysis.
\end{abstract}

Keywords: teacher education, videocase, video in teacher education

\section{1 Úvod}

Předkládaný příspěvek si klade za cíl představit videopřípad jakožto základní jednotku elektronického učebního prostředí IVŠV videoweb pro vzdělávání učitelů anglického jazyka. V následujícím textu stručně představíme koncept videopřípadů i jejich konkrétní strukturu v rámci IVŠV videowebu. V souvislosti s jejich strukturou př́edstavíme i teoretická východiska a cíle tohoto učebního prostředí.

\section{IVŠV videoweb}

Jak bylo zmíněno výše, IVŠV videoweb je elektronické učební prostředí, které využívá videozáznamy reálné výuky. Zdrojem jsou videozáznamy pořízené v rámci CPV videostudií

\footnotetext{
${ }^{1}$ Př́spěvek vznikl v rámci řešení projektu MUNI/A/1020/2010 Nástroje pro monitoring a evaluaci kvality ve vzdělávání (NAME 2011). Jeho prezentace na konferenci byla podpořena Stipendijním fondem PdF MU.
} 
(např. Najvar et al., 2008). K vybraným videosekvencím (části hodin) jsou vytvořeny otázky a úlohy, na které studenti reagují v rámci elektronického učebního prostředí. Součástí videowebu mohou být i další materiály (plány hodin, rozhovory s učiteli apod.), synchronní a asynchronní fóra atd. Videoweb vzniká současně pro několik předmětů (Janík, Minaříková et al., 2011, s. 105-152). Jeho součástí jsou i moduly na předmětech nezávislé, např. modul výukové komunikace a interakce (Šmerdová, 2011, s. 153-172).

IVŠV videoweb pro vzdělávání učitelů anglického jazyka si klade za cíl rozvoj a hodnocení jejich diagnostické kompetence. Tento koncept bude stručně představen v následující podkapitole.

\section{Diagnostická kompetence}

Pojetí diagnostické kompetence se u různých autorů liší. V literatuře lze najít různých rozsah dílčích schopností, které autoři diagnostické kompetenci přiřazují, i různou šíři předmětu diagnostické kompetence. V nejužším pojetí se může jednat jen o hodnocení výkonu žáka (např. Arnold, 1999) nebo o schopnost zacházet s testovými materiály (Edelenbos \& Kubanek-German, 2004). V širším pojetí diagnostické kompetence (a u konceptů př́buzných) je předmětem diagnostikování celá třída (Švec, 1999) nebo komplexní výuková situace (Janík et al., 2009; Seidel, Blomberg, \& Stürmer, 2010).

Na základě teoretické literatury i empirických studií předkládáme pokus o syntézu různých pojetí diagnostické kompetence, kterou vymezujeme jako schopnost identifikovat a popsat, interpretovat a vysvětlit, hodnotit, predikovat a nabízet alterace výukových situací. Vztah našeho pojetí k prŕíbuzným konceptům je zachycen v tabulce 1 .

Tabulka 1

Diagnostická kompetence a př́buzné koncepty

\begin{tabular}{|c|c|c|c|c|c|c|c|}
\hline $\begin{array}{l}\text { Diagnostická } \\
\text { kompetence je } \\
\text { schopnost: }\end{array}$ & 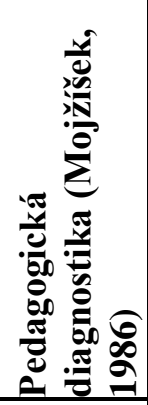 & 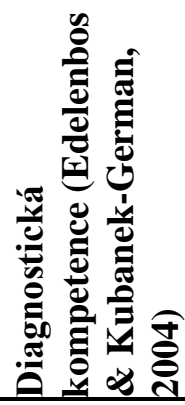 & 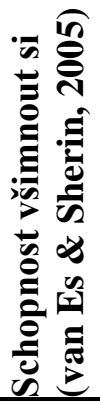 & 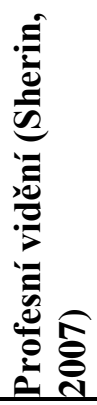 & 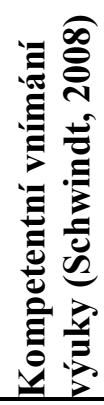 & 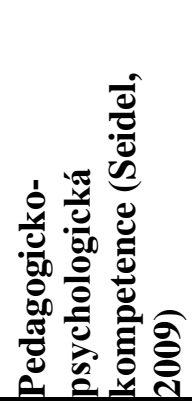 & 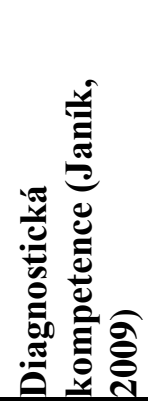 \\
\hline Identifikovat & $\mathbf{x}$ & & $\mathbf{x}$ & $\mathbf{x}$ & $\mathbf{x}$ & $\mathbf{x}$ & $\mathbf{x}$ \\
\hline Popsat & & & & & $\mathbf{x}$ & $\mathbf{x}$ & $\mathbf{x}$ \\
\hline Interpretovat & & $\mathbf{x}$ & & & & & $\mathbf{x}$ \\
\hline Vysvětlit & & & $\mathbf{x}$ & $\mathbf{X}$ & $\mathbf{x}$ & $\mathbf{x}$ & $\mathbf{x}$ \\
\hline Hodnotit & & & & & $\mathbf{x}$ & $\mathbf{x}$ & $\mathbf{x}$ \\
\hline Predikovat & & & & & $\mathbf{x}$ & $\mathbf{x}$ & $\mathbf{x}$ \\
\hline $\begin{array}{l}\text { Navrhovat } \\
\text { alterace } \\
\text { výukových } \\
\text { situací }\end{array}$ & $\mathbf{x}$ & & & & $\mathbf{x}$ & & \\
\hline
\end{tabular}


IVŠV videoweb pro vzdělávání učitelů anglického jazyka si klade dva cíle - rozvoj a hodnocení diagnostické kompetence (budoucích) učitelů anglického jazyka. Těchto cílů může být dosáhováno pomocí videopřípadů. Následující podkapitola představí strukturu dvou typů videopřípadů (rozvíjející a diagnostické), které zmíněné cíle sledují.

\section{Videopř́pady}

Videopř́ípad je multimediální reprezentace výukové situace, která obsahuje vybranou videosekvenci hodiny, případně videozáznam celé vyučovací hodiny a k ní se vztahující otázky/úkoly. Dále může zahrnovat psanou analýzu dané hodiny či její videozáznam (autorem může být učitel z videozáznamu, expert, student atd.) a další materiály (plán hodiny, výtvory žáků apod.; Richardson \& Kile, 1999, s. 122).

IVŠV videoweb pro vzdělávání učitelů anglického jazyka využívá dva typy videopřípadů diagnostické a rozvíjející.

Cílem diagnostických videopř́padi̊ v IVŠV videowebu je hodnotit úroveň diagnostické kompetence (budoucích) učitelů anglického jazyka. Struktura těchto videopřípadů je vždy stejná. Uživatelé videowebu nejprve shlédnou vybranou videosekvenci z výuky anglického jazyka, doprovázenou stručným popisem kontextu (typ školy, ročník, počet studentů, fáze hodiny apod.). Po zhlédnutí odpovídají na obecnou otázku (napřr. Okomentujte zhlédnutou videosekvenci.). Po této otázce následuje pět konkrétních otázek, které se zaměřují na pět dimenzí diagnostické kompetence ${ }^{2}$. Odpovědi, které uživatelé zaznamenávají do příslušného dialogového okna, budou následně kódovány pomocí ratingového systému pro zachycení úrovně diagnostické kompetence (Minaříková, 2011). Strukturu diagnostických videopř́iapdů zachycují obrázky 1 a 2.

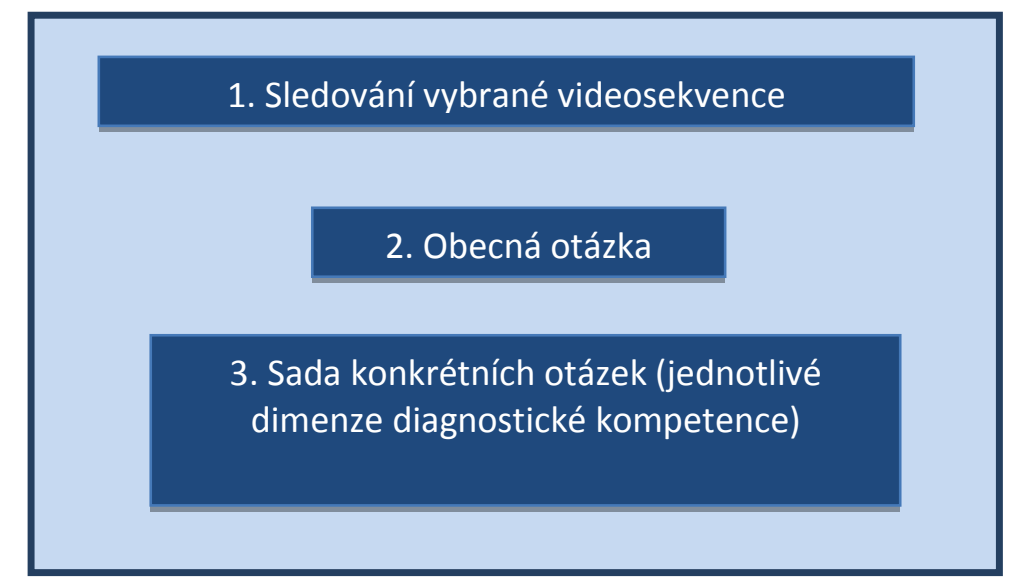

Obrázek 1. Struktura diagnostického videopřípadu

\footnotetext{
2 (1) identifikovat a popsat, (2) interpretovat a vysvětlit, (3) hodnotit, (4) predikovat, (5) nabízet alterace výukových situací (podrobněji viz Minaříková, 2011).
} 
Obrázek 2

Př́klady otázek a úkolư v diagnostickém videopřipadu

\section{Obecná otázka}

Prosím okomentujte videosekvenci, kterou jste viděli.

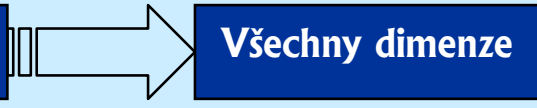

\section{Konkrétní otázky}

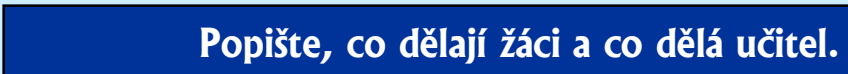

Identifikace a

opište, co dělaji žáci a co dělá učitel.

Co je cílem aktivity a proč si učitel vybral tuto aktivitu

$v$ této fázi hodiny?

Intepretace a

vysvětlení

Ohodnot'te práci učitele v této videosekvenci.

Myslíte si, že si žáci nová slovíčka zapamatují?

Navrhněte jinou aktivitu, která by sledovala stejný cíl.

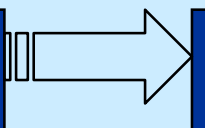

popis

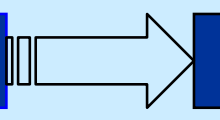

Hodnocení

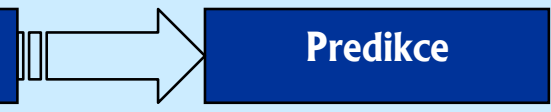

Alterace

Rozvijejici videoprípady jsou inspirovány metodikou hospitačních videostudií (Janík, Slavík, \& Najvar et al., 2011). Postup hospitačních videostudií se skládá ze tří kroků - anotace, analýza a alterace - ve kterých lze identifikovat jednotlivé dimenze diagnostické kompetence (anotace - identifikace a popis; analýza - intepretace a vysvětlení; alterace - hodnocení, predikce, alterace).

Rozvíjející videopř́ípady se tedy skládají z videosekvence $\mathrm{z}$ reálné výuky (doprovázené informacemi o kontextu, př́ípadně dalšími materiály), kterým mohou předcházet úkoly k zaměření pozornosti, následované otázkami a úkoly, které mají za úkol nasměrovat myšlení (budoucích) učitelů anglického jazyka žádoucím směrem. Otázky a úkoly směřují nejprve $\mathrm{k}$ anotaci videosekvence (identifikování důležitých momentů a jejich popis). Na základě tohoto popisu pak budou mít (budoucí) učitelé za úkol výukovou situaci analyzovat (interpretovat a vysvětlit popsané události). Na základě analýzy se je další otázky a úkoly snaží dovést ke zhodnocení výukové situace, predikci jejích důsledků a také k navržení žádoucích alterací. Závěrem se musí (budoucí) učitelé zamyslet i nad navrženou alterací a jejími možnými úskalími. Obrázek 3 shrnuje strukturu rozvíjejících videopřípadů. 
Obrázek 3

Struktura rozvíjejicího videopř́padu

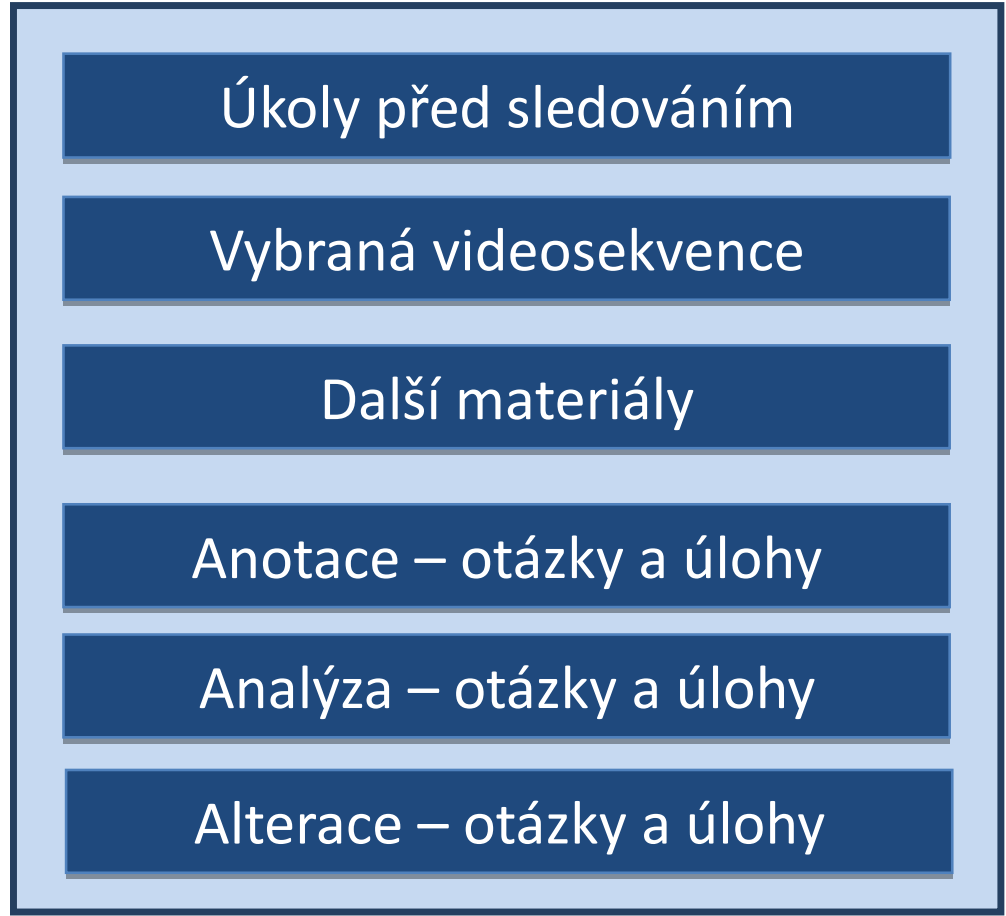

Diagnostické a rozvíjející videopřípady se vzájemně doplňují. Diagnostické videopř́ípady umožňují identifikovat, které dimenze diagnostické kompetence jsou u (budoucích) učitelů méně rozvinuté, což může pomoci lépe zaměřit a strukturovat videoprř́pady rozvíjející. Účinnost intervence (tedy rozvíjejících videoprrípadů) lze poté zhodnotit diagnostickými videopř́ípady.

\section{Závěr}

Předkládaný příspěvek stručně představil elektronické učební prostředí využívající videozáznamy reálné výuky IVŠV videoweb pro vzdělávání učitelů anglického jazyka, jeho cíle a videopř́ípad jako základní stavební jednotku. V textu byla stručně popsána struktura diagnostických a rozvíjejících videopř́ípadů. V návaznosti na cíle IVŠV videowebu pro učitele anglického jazyka bylo představeno i námi rozvíjené pojetí diagnostické kompetence.

\section{Literatura}

Arnold, K. H. (1999). Diagnostische kompetenz erwerben. Pädagogik, 20(7-8), 72-77.

Edelenbos, P., \& Kubanek-German, A. (2004). Teacher assessment. The concept of „diagnostic competence". Language Testing, 21(3), 259-283.

Janík, T., \& Minaříková, E., et al. (2011). Video v učitelském vzdělávání: teoretická východiska, aplikace, výzkum. Brno: Paido.

Janík, T., Slavík, J., \& Najvar, P., et al. (2011). Kurikulární reforma na gymnáziích: od virtuálních hospitaci k videostudiím. Praha: VÚP v Praze.

Minaříková, E. (2011). Nástroj pro zkoumání diagnostické kompetence (budoucích) učitelů. In T. Janík, P. Najvar, \& M. Kubiatko et al., Kvalita kurikula a výuky: výzkumné přistupy a nástroje. Brno: Paido (v tisku).

Mojžíšek, L. (1986). Základy pedagogické diagnostiky. Praha: SPN. 
Najvar, P., Najvarová, V., Soběslavská, V., Šebestová, S., Vlčková, K., \& Zerzová, J. (2008). CPV videostudie anglického jazyka: sběr dat a zamýšlené analýzy. Orbis scholae, 2(1), 73-91.

Richardson, V., \& Kile, R. S. (1999). Learning from videocases. In M. A. Lundeberg, B. B. Levin, \& H. L. Harrington (Eds.), Who Learns What from Cases and How? (pp. 121-136). New Jersey: Lawrence Erlbaum Associates.

Seidel, T., Prenzel, M., Schwindt, K., Stürmer, K., Blomberg, G., \& Kobarg, M. (2009). LUV and observe: Two projects using video to diagnose teachers' competence. In T. Janík, \& T. Seidel (Eds.), The Power of Video Studies in Investigating Teaching and Learning in Classroom (pp. 243-258). Münster: Waxmann Verlag.

Seidel, T., Blomberg, G., \& Stürmer, K. (2010). „Observer“ - Validierung eines videobasierten instruments zur erfassung der profesionellen wahrnehmung von unterricht. Zeitschrift für Pädagogik, 56(Beiheft), 296-306.

Sherin, M. G. (2007). The Development of teachers' Professional vision in video clubs. In R. Goldman, R. Pea, B. Barron, \& S. J. Derry (Eds.), Video Research in the Learning Sciences (pp. 383-395). London: Lawrence Erlbaum Associates Publishers.

Sherin, M. G., \& Van Es, E. A. (2005). Using video to support teacher's ability to notice classroom interactions. Journal of Technology and Teacher Education, 13(3), 475-491.

Schwindt, K. (2008). Lehrpersonen betrachten Unterricht (Kriterien für die kompetente Unterrichtswahrnehmung). Münster: Waxmann.

Šmerdová, D. (2011). CPV Videoweb: Modul výukové komunikace a interakce. In T. Janík \& E. Minaříková et al., Video v učitelském vzdělávání: teoretická východiska, aplikace výzkum (pp. 153-172). Brno: Paido.

Švec, V. (1999). Pedagogická připrava budoucích učiteli̊: Problémy a inspirace. Brno: Paido.

\section{Kontakt}

Mgr. Eva Minaříková

Masarykova univerzita

Pedagogická fakulta, Institut výzkumu školního vzdělávání

Poříčí 31, Brno 60300

e-mail: eminarikova@seznam.cz

\section{Bibliografické údaje}

Minaříková, E. (2011). Videopřípad jako stavební jednotka IVŠV videowebu pro vzdělávání učitelů anglického jazyka. In T. Janík, P. Knecht, \& S. Šebestová (Eds.), Smišsený design v pedagogickém výzkumu: Sbornik př̀spěvků z 19. výročni konference České asociace pedagogického výzkumu (s. 162167). Brno: Masarykova univerzita.

Dostupné z: http://www.ped.muni.cz/capv2011/sbornikprispevku/minarikova.pdf doi: 10.5817/PdF.P210-CAPV-2012-39 